\title{
DETERMINATION THE EFFECT OF FACTORS AFFECTING THE TENSILE STRENGTH OF FABRIC CONVEYOR BELTS
}

\section{OCENA WPŁYWU CZYNNIKÓW NA WYTRZYMAŁOŚĆ NA ROZCIĄGANIE TAŚM PRZENOŚNIKOWYCH TKANINOWO - GUMOWYCH}

\author{
The Design of experiment (DOE) method was used in this paper to rubber conveyor belt tension testing. Using DOE method were \\ from experimentally obtained data established effects of factors and interactions that affect the value of the measured strength and \\ also were determined regression models, which apply input and output variables to the relation. The regression model presents the \\ complete multifactor experiment that contains main factors and interactions.
}

Keywords: mechanical testing, tension, conveyor belt, DOE method (Design of Experiments).

\begin{abstract}
Metoda planowania eksperymentu (DOE) w artykule użyta do testowania napięcia taśm przenośnikowych tkaninowo - gumowych. Korzystanie z metody DOE byly ustalonych poszczególnych czynników oraz ich interakcji ze danych uzyskanych w sposób doświadczalny. Czynniki i interakcje wpływające na wartość zmierzonej wytrzymatośći, a także określono modele regresji, wykazajacego zwiąki pomiędzy zmiennymi wejściowymi i wyjściowymi. Model regresyjny przedstawia kompletny wieloczynnikowy eksperyment obejmujacy podstawowe zmienne oraz ich interakcje.
\end{abstract}

Slowa kluczowe: testy mechaniczne, napięcie, taśma przenośnikowa, metoda DOE.

\section{Introduction}

Belt conveyor system is a high-power conveyance system broadly applied in practice [16]. The main reason of such broad application is its structural and economic adaptability [26]. According to [14, 25], a belt conveyor represents the most cost-effective solution in the loose material transportation. It can be broadly used in the fields, such as coal mining, ports, chemical industry, electric energy, metallurgy, architecture, and food supplies [13]. Requirements demanded by production plants regarding minerals are currently rising, which results in the increasing traffic intensity of material flows in mining companies within the transportation of bulk solid materials. Bulk materials are currently transported mainly by trucks. Therefore, an alternative to this kind of transport must be searched [21, 23]. Transportation solution is offered by the continuous belt conveyor system with the crushing carried out directly in the quarry, using portable crushers [6].

Large scale belt conveyor is a key (one of the most important) device to transport bulk-solid material for long distance at high rates [5]. Belt conveyors are complex systems with drive groups as functionally very important components [15]. For belt conveyors, the transport task can be defined as a process whose purpose is to transport the set quantity of handled material within a defined time between the set loading and offloading locations [12].

Due to the fact that a conveyor belt, as a carrying and tractive element, represents the most important part of a belt conveyor, it is essential to reduce the costs of manufacture and maintenance thereof. Maintenance cost reduction can be achieved by improvements in utility properties of conveyor belts [16]. Conveyor belt properties significantly affect the reliability of the entire belt conveyor system. Insufficient strength of a conveyor belt can cause its rupture and subsequent downtime due to repair and replacement thereof. Rupture of a conveyor belt represents unacceptable risk in the operation of a belt conveyor system and [3] classify it as unsystematic risk in an underground mine plant.

During the operation, a conveyor belt is affected by various stresses that cause its damage and wear-out [8]. Awareness of mechanical properties of conveyor belts is very important for a smooth operation of belt conveyors [24]. Requirements regarding conveyor belts depend on the method of their use; therefore, entire belt conveyor, as well as its individual components, is subject to compulsory tests. Required properties of conveyor belts are identified by tests determined by standards and technical or technological regulations.

According to Hardygora [10] and Taraba [22] tests of conveyor belts can be divided into three groups: standard tests, certification tests and non-standard tests. The first group includes tests of physicomechanical properties for their compliance with the standards in force. The second group comprises certification tests on belts required for permitting the latter to be operated in underground mines. The third group embraces non-standard tests - specialist tests performed on special test stands, usually not covered by standards but concerning parameters important for the operation of belts.

Non-standard tests include, for example, determination of the impact resistance of a conveyor belt. The methodology of testing the impact resistance using a special testing equipment is described by authors [7] and determination of impact resistance on the basis of experimental measurements, with the results evaluation using the regression analysis, is described by authors $[1,4]$. By using DOE methods in the examining stress conveyor belts in relation to their resistance to breakdown deal works $[2,9]$.

Conveyor belt tests carried out within the experimental research and the results presented in this article can be classified as the group 1 st tests, according to [10]. In addition to the results obtained by standard testing, the article presents a new approach to the evalua- 
tion thereof, with the determination of the impact of the selected factors on the tensile strength of a conveyor belt.

\section{Materials and experimental proce- dure}

\subsection{Experimental material}

A belt conveyor as a composite consists of several materials. Fabric conveyor belts usually consist of a wear resistant top layer ('top cover'), a fabric carcass providing tensile strength, skim layers for adhesion between rubber and carcass, and a bottom layer ('bottom cover') to cover the carcass and provide sufficient friction to the drive pulley [18].

Experiments were carried out using conveyor belts (CB) of TRANSBELT type intended for general use. They are textile conveyor belts intended for the transportation of loose and piece materials in common operating conditions. They are typically used in the mining and processing industries, as well as in operations, such as gravel sand works, lime works, cement works, thermal power plants, dumps and docks. Their cover layers (CL) are made of rubber in five categories, depending on the type of transported material. The conveyor belt carcass (Fig. 1) consists of one to five fabric plies. The plies are made in two versions. In the first version, individual layers of fabric reinforcement are made of polyamide fibres in the lengthwise and transversal direction. In case of polyamide reinforcement material, the mark of a conveyor belt type contains letter P. In the second version, individual plies are made of the combination of polyamide and polyester fibres.



Fig. 1. Structure of a conveyor belt with a textile carcass 1 -top cover layer, 2 - carcass, 3 -adhesive mixture, 4 - protective rubber selvage, 5 bottom cover layer, 6 -fabric plies, 7 - bumper

Table 1. Used types of conveyor belts

\begin{tabular}{|c|c|c|c|c|c|c|}
\hline \multirow{2}{*}{ Ord. no. } & \multicolumn{2}{|c|}{ Carcass material } & \multirow{2}{*}{$\begin{array}{l}\text { Nominal tensile strength } \\
\qquad[\mathrm{N} / \mathrm{mm}]\end{array}$} & \multirow{2}{*}{$\begin{array}{l}\text { Number } \\
\text { of layers }\end{array}$} & \multirow{2}{*}{ CL category } & \multirow{2}{*}{ CB mark } \\
\hline & Warp & Woof & & & & \\
\hline 1. & $P$ & $P$ & 800 & 3 & $\mathrm{AA}$ & $\mathrm{P} 800 / 3 \mathrm{AA}$ \\
\hline 2. & $P$ & $P$ & 800 & 4 & AA & P 800/4 AA \\
\hline 3. & E & $P$ & 800 & 3 & $\mathrm{AA}$ & EP 800/3 AA \\
\hline 4. & E & $P$ & 800 & 4 & AA & EP 800/4 AA \\
\hline 5. & $P$ & $P$ & 1000 & 3 & $\mathrm{AA}$ & P 1000/3 AA \\
\hline 6. & $\mathrm{P}$ & $\mathrm{P}$ & 1000 & 4 & $\mathrm{AA}$ & P 1000/4 AA \\
\hline 7. & $\mathrm{E}$ & $P$ & 1000 & 3 & $\mathrm{AA}$ & EP 1000/3 AA \\
\hline 8. & $\mathrm{E}$ & $\mathrm{P}$ & 1000 & 4 & AA & EP 1000/4 AA \\
\hline 9. & $P$ & $P$ & 1250 & 3 & $\mathrm{AA}$ & P 1250/3 AA \\
\hline 10. & $P$ & $P$ & 1250 & 4 & $\mathrm{AA}$ & P 1250/4 AA \\
\hline 11. & $\mathrm{E}$ & $P$ & 1250 & 3 & $\mathrm{AA}$ & EP 1250/3 AA \\
\hline 12. & E & $P$ & 1250 & 4 & AA & EP 1250/4 AA \\
\hline
\end{tabular}

In such case, polyester fibres are used in the lengthwise direction of the fabric (in warp). Transverse direction of a ply, also called woof, consists of polyamide fibres. In such version of the fabric reinforcement, a conveyor belt type is marked with letters EP. Experiments were carried out using CBs (Table 1) with cover layers of AA category - for the transportation of very abrasive, grainy, and loose material. Required mechanic properties of the examined CBs are listed in Table 2.
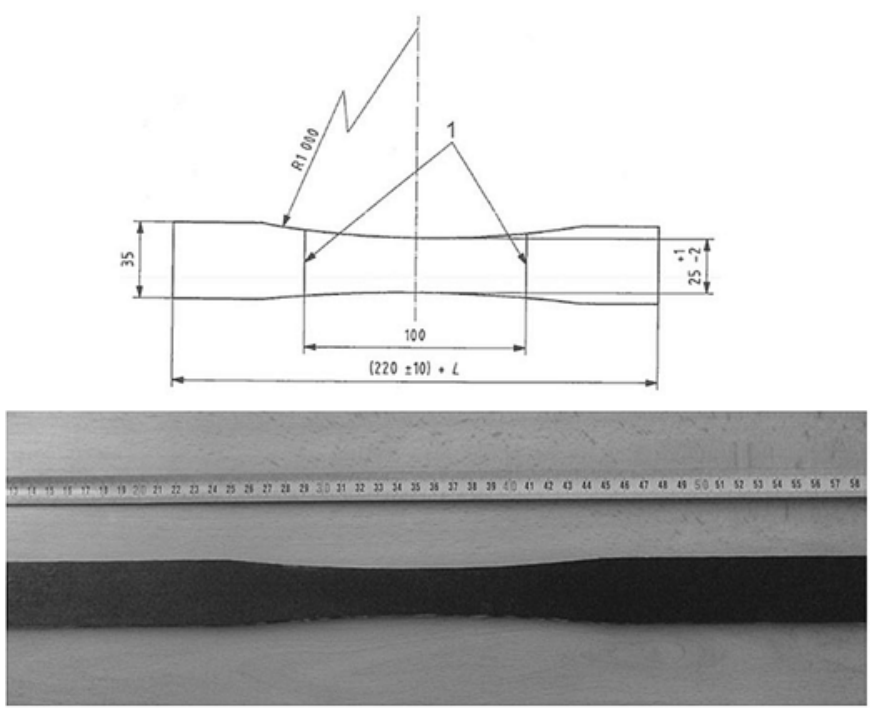

Fig. 2. Type A testing specimen, L-Testing specimen length [mm], 1 - reference lines

\subsection{Testing specimens}

Type A testing specimens were prepared using a cutting die by cutting them out from each type of a conveyor belt in the quantity of three pieces, in the lengthwise direction, as specified in [11]. None of the ply objects contained joints. Shapes and dimensions of testing specimens are documented in Fig. 2. Two reference lines were drawn on the testing specimens across their lengthwise axes in their working sections, in the distance of 100 $\mathrm{mm}$. Subsequently, these objects were conditioned pursuant to [11]. Tensile tests were carried out immediately after the conditioning period terminated. 


\subsection{Test fundamentals and procedure}

Test fundamentals - a testing specimen, cut out from the whole thickness of a conveyor belt, is loaded, under the prescribed conditions, on the tensile testing equipment, applying the tension, until the testing object disturbance is observed. Experimental tests of mechanical properties of conveyor belts were carried out using a testing machine of the Zwick Roell Z 100 type. Due to the need to measure the elongation of the testing specimen during the test, the testing machine was equipped with the videoXtens extensometer, which applies the contactless deformation measurement principle. The main advantage of this extensometer is that it can be used until the sample's rupture without any damage. A full-area camera scans a digitalized image of a tested specimen and processes it in the real time. The system automatically identifies reference marks, while calculating their displacement as the specimen is loaded [27].

Test procedure - Testing specimens were symmetrically fixed between grips of the testing machine so that the lengthwise axes of a testing object, the central line of the grip, and the direction of tensile force were aligned. Testing specimens were loaded with the constant loading rate of $100 \mathrm{~mm} / \mathrm{min}$. During the test, elongation was recorded at the instance of reaching the reference load, corresponding to one tenth of the nominal tensile strength in the lengthwise direction (Table 2), multiplied by the width of the testing specimen in $\mathrm{mm}$. The testing continued, until the specimen's rupture, first signs of carcass disturbance, or reaching the maximum value on the force measuring device. This maximum force and the elongation at such force were recorded. The same procedure was carried out with all testing objects. Recorded values are invalid, if a testing specimen is not disturbed between the reference lines, or if during the test the specimen is skidding between the grips [20], which, however, did not happen.

\subsection{Determination of mechanical properties}

Experimental research determined the following mechanical properties of the examined CBs, determined pursuant to [19]:

- Full thickness tensile strength - the most intensive force measured during the tensile test, divided by the testing specimen's width:

$$
f_{s}=\frac{F_{r}}{b_{t}}
$$

Table 3. Maximum measured values of mechanical properties of the examined CBs

\begin{tabular}{|c|c|c|c|c|c|c|c|c|c|c|c|c|}
\hline \multirow{2}{*}{ Type CB } & \multicolumn{4}{|c|}{$f_{s}[N / m m]$} & \multicolumn{4}{|c|}{$\varepsilon_{\mathrm{r}}[\%]$} & \multicolumn{4}{|c|}{$\varepsilon_{t}[\%]$} \\
\hline & $x_{1}$ & $x_{2}$ & $x_{3}$ & $\bar{a}\left(x_{i}\right)$ & $x_{1}$ & $x_{2}$ & $x_{3}$ & $\bar{a}\left(x_{i}\right)$ & $\mathrm{x}_{1}$ & $x_{2}$ & $x_{3}$ & $\bar{a}\left(x_{i}\right)$ \\
\hline P 800/3 & 893 & 979 & 939 & 937 & 19 & 20 & 20 & 19.7 & 1.1 & 1.2 & 1.2 & 1.2 \\
\hline P 800/4 & 1004 & 1009 & 987 & 1000 & 22 & 22 & 22 & 22.0 & 1.3 & 1.4 & 1.5 & 1.4 \\
\hline EP $800 / 3$ & 943 & 885 & 942 & 923 & 18 & 18 & 18 & 18.0 & 1.0 & 1.1 & 1.1 & 1.1 \\
\hline EP 800/4 & 1050 & 1069 & 1059 & 1059 & 19 & 19 & 19 & 19.0 & 0.9 & 0.9 & 0.9 & 0.9 \\
\hline P 1000/3 & 1250 & 1255 & 1275 & 1260 & 25 & 24 & 25 & 24.7 & 1.5 & 1.6 & 1.6 & 1.6 \\
\hline P $1000 / 4$ & 1240 & 1167 & 1209 & 1205 & 24 & 22 & 23 & 23.0 & 2.4 & 2.6 & 2.5 & 2.5 \\
\hline EP $1000 / 3$ & 1270 & 1239 & 1219 & 1243 & 19 & 18 & 18 & 18.3 & 1.1 & 1.2 & 1.4 & 1.2 \\
\hline EP $1000 / 4$ & 1240 & 1250 & 1290 & 1260 & 18 & 19 & 19 & 18.7 & 0.9 & 1.0 & 0.8 & 0.9 \\
\hline P 1250/3 & 1460 & 1500 & 1471 & 1477 & 22 & 22 & 22 & 22.0 & 1.6 & 1.7 & 1.7 & 1.7 \\
\hline P 1250/4 & 1583 & 1569 & 1660 & 1604 & 24 & 25 & 25 & 24.7 & 1.5 & 1.6 & 1.5 & 1.5 \\
\hline EP $1250 / 3$ & 1575 & 1580 & 1581 & 1579 & 20 & 20 & 20 & 20.0 & 0.8 & 0.7 & 0.7 & 0.7 \\
\hline EP $1250 / 4$ & 1830 & 1667 & 1791 & 1763 & 18 & 18 & 18 & 18.0 & 1.1 & 1.3 & 1.2 & 1.2 \\
\hline
\end{tabular}

Table 4. Minimum measured values of mechanical properties of the examined CBS

\begin{tabular}{|c|c|c|c|c|c|c|c|c|c|c|c|c|}
\hline Type CB & \multicolumn{4}{|c|}{$f_{s}[N / m m]$} & \multicolumn{4}{|c|}{$\varepsilon_{\mathrm{r}}[\%]$} & \multicolumn{4}{|c|}{$\varepsilon_{t}[\%]$} \\
\hline P 800/3 & 862 & 848 & 870 & 860 & 23 & 22 & 22 & 22.3 & 1.8 & 1.6 & 1.7 & 1.7 \\
\hline P 800/4 & 950 & 968 & 970 & 963 & 21 & 21 & 21 & 21.0 & 1.4 & 1.3 & 1.3 & 1.3 \\
\hline EP 800/3 & 884 & 835 & 894 & 871 & 18 & 19 & 18 & 18.3 & 1.3 & 1.2 & 1.1 & 1.2 \\
\hline P 1000/3 & 1167 & 1180 & 1220 & 1189 & 27 & 26 & 25 & 26.0 & 1.8 & 1.7 & 2.1 & 1.9 \\
\hline P 1000/4 & 1102 & 1074 & 1100 & 1092 & 20 & 20 & 20 & 20.0 & 1.5 & 1.6 & 1.6 & 1.6 \\
\hline EP $1000 / 3$ & 1159 & 1138 & 1156 & 1151 & 17 & 16 & 17 & 16.7 & 0.9 & 0.9 & 1.0 & 0.9 \\
\hline EP $1000 / 4$ & 1127 & 1122 & 1126 & 1125 & 17 & 18 & 18 & 17.7 & 1.0 & 1.1 & 1.1 & 1.1 \\
\hline EP $1250 / 3$ & 1333 & 1342 & 1340 & 1338 & 18 & 18 & 18 & 18.0 & 1.1 & 1.1 & 1.1 & 1.1 \\
\hline EP $1250 / 4$ & 1291 & 1295 & 1315 & 1300 & 21 & 21 & 20 & 20.7 & 0.8 & 0.8 & 0.7 & 0.8 \\
\hline
\end{tabular}


where $f_{s}-$ tensile strength $[\mathrm{N} / \mathrm{mm}]$,

$F_{r}-$ sample load force at rupture [N],

$b_{t}-$ specimen width [mm].

The resulting value of the tensile strength is the arithmetic average of the values for three testing objects in the lengthwise direction.

- Elongation at break - elongation at the maximum force expressed as the percentage gain in the distance between two reference lines

$$
\varepsilon_{r}=\frac{\left(L_{2}-L_{1}\right)}{L_{1}} \cdot 100
$$

where $\varepsilon_{r}$ - elongation at break [\%],

$L_{1}$ - distance between reference lines prior to loading [mm],

$L_{2}$ - distance between reference lines at specimen's disturbance $[\mathrm{mm}]$.

- Elongation at the reference load - is expressed as the percentage gain in the distance between two reference lines with the reference force:

$$
\varepsilon_{t}=\frac{\left(L_{R}-L_{1}\right)}{L_{1}} \cdot 100
$$

where $\varepsilon_{t}$-elongation at the reference load [\%],

$\mathrm{L}_{\mathrm{R}}$ - distance between reference lines with the reference load of the testing specimen $[\mathrm{mm}]$,

$\mathrm{L}_{1}$ - distance between reference lines prior to loading [mm].

The resulting value of the elongation at break and the elongation at the reference load is the arithmetic average of values for three testing objects in the lengthwise direction.

For each examined type of a conveyor belt, we tested the testing objects marked as $x_{i}$, where $i=1,2,3$. Results of the measurements are listed in Tables 3 and 4.

\section{Design and evaluation of experiment}

In this work, we monitored the impact of three main factors (Table 5): nominal strength, i.e. specified minimum value of the tensile strength (factor A), type of carcass (factor B), and number of plies (factor $\mathrm{C}$ ). Our task was to determine which of the factors, or which of their interactions, have a significant impact on the response, i.e. the tensile strength of a conveyor belt.

We have developed a plan of the complete three-factor experiment with two levels without repetition together with two-factor interactions (first-order interactions), whereas the number of all steps is $2^{3}$ - the square root represents the number of levels and the exponent represents the number of factors. For one experiment design, it was necessary to enter 8 values of the response on the upper and lower levels of each factor, which are listed in Tables 3 and 4. For the DOE method, maximum and minimum values of measured tensile strength of CBs were applied separately for 3 strength intervals: a) 800 and $1,250 \mathrm{~N} / \mathrm{mm}$, b) 800 and $1,000 \mathrm{~N} / \mathrm{mm}$, c) 1,000 and $1,250 \mathrm{~N} / \mathrm{mm}$; i.e. totally 6 designs of experiment. Each experiment design can be

Table 5. List of input factors and their levels

\begin{tabular}{rccc}
\hline \hline & Factors & $\begin{array}{c}\text { Low level } \\
(-1)\end{array}$ & $\begin{array}{c}\text { High level } \\
(+1)\end{array}$ \\
\hline A & Nominal strength $[\mathrm{N} / \mathrm{mm}]$ & $X_{\mathrm{i}}$ & $X_{\mathrm{j}}$ \\
B & Carcass type [-] & $\mathrm{P}$ & $\mathrm{EP}$ \\
C & Number of plies [-] & 3 & 4 \\
\hline \hline Where: & $X_{i} X_{j}$ : a) $X_{1} X_{3} 800$ and $\left.1,250 \mathrm{~N} / \mathrm{mm}, b\right) X_{1} X_{2} 800$ and $1,000 \mathrm{~N} / \mathrm{mm}$, \\
& c) $X_{2} X_{3} 1,000$ and $1,250 \mathrm{~N} / \mathrm{mm}$
\end{tabular}

graphically represented using a cube (Fig. 3), whereas cube corners contain the entered response values.

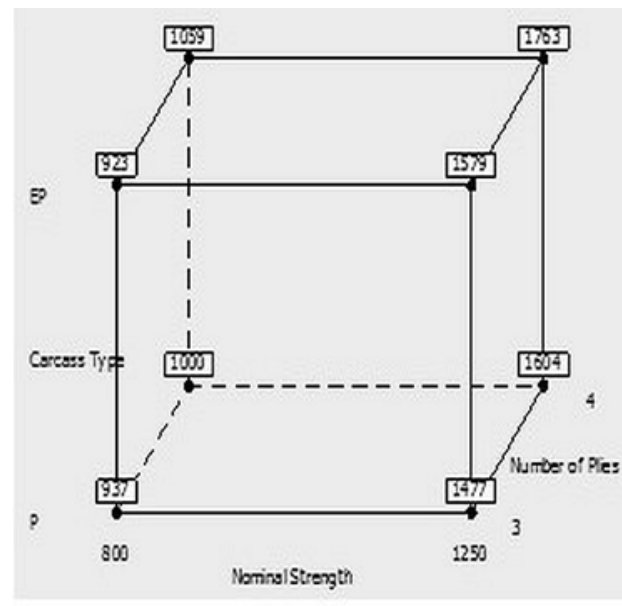

Fig. 3. Graphical representation using cube

\subsection{Designs of experiments for maximum response values}

In the assessment of the significance of effects and their interactions, the DOE method facilitates the use of several graphical outputs, such as:

- Graphical representation of main effects;

- Normal probability plot of the significance of factors and interactions;

- Interaction plot of main effects.

As several individual experiments designs were carried out, the most frequently used Pareto chart was selected (Fig. 4), which defines factors and interactions with the statistically significant impact on the monitored response. Significance of individual impacts of factors or interactions was tested using the t-test and by the determination of the $p$-value on the significance level of $\alpha=0.05$. In all the monitored intervals for the maximum values of the measured tensile strength of CBs, statistically significant impact of three main factors was confirmed. Insignificant impact on the measured tensile strength value was observed only in certain first-order interactions.
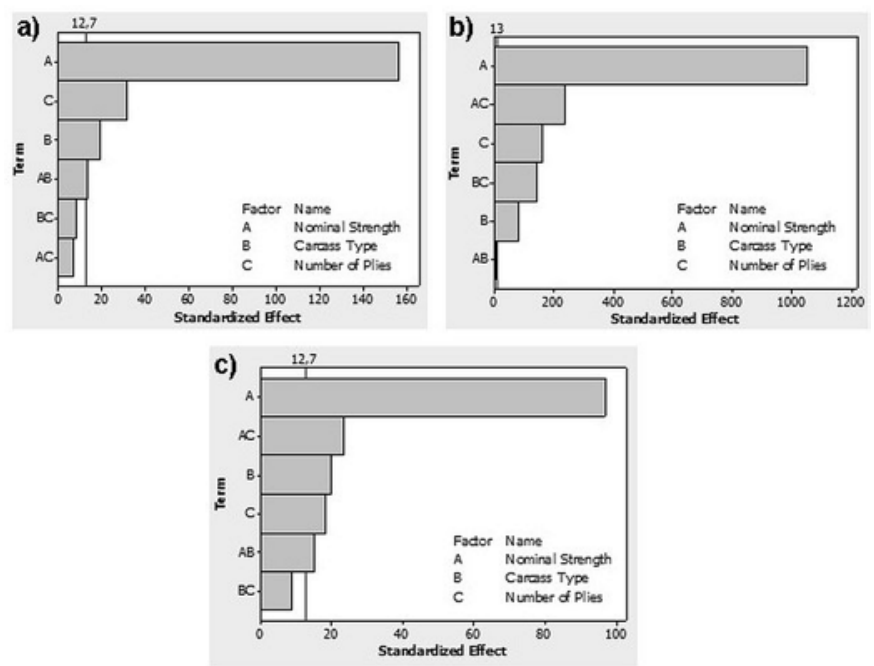

Fig. 4. The Pareto chart of the significance of factors and interactions; a) 800 and $1,250 \mathrm{~N} / \mathrm{mm}$, b) 800 and $1,000 \mathrm{~N} / \mathrm{mm}$, c) 1,000 and $1,250 \mathrm{~N} / \mathrm{mm}$

Table 6 shows the average values of the response on the upper and lower level of each factor, as well as effects of individual factors. 
Table 6. The main effects of factors

\begin{tabular}{lccc}
\hline \hline $800 \& 1250$ & A & B & C \\
\hline $\bar{y} .-$ (low level) & 979.75 & 1254.5 & 1229 \\
$\bar{y} \cdot+$ (high level) & 1605.75 & 1331 & 1356.5 \\
Effect of factors & 626 & 76.5 & 127.5 \\
\hline 800 \& 1000 & & & \\
$\bar{y} \cdot-$ (low level) & 979.75 & 1121.25 & 1131 \\
$\bar{y} \cdot+$ (high level) & 1242 & 1100.5 & 1090.75 \\
Effect of factors & 262.25 & 20.75 & 40.25 \\
\hline 1000 \& 1250 & & & \\
$\bar{y} .-$ (low level) & 1242 & 1386.5 & 1389.75 \\
$\bar{y} \cdot+$ (high level) & 1605.75 & 1461.25 & 1458 \\
Effect of factors & 363.75 & 74.75 & 68.25 \\
\hline \hline
\end{tabular}

The strongest significance on the monitored response in all strength intervals was observed in factor A (nominal strength).

The model of a full three-factors experiment containing the main factors and all two-factors interactions is determined by the relation:

$$
y=\beta_{0}+\beta_{1} x_{1}+\beta_{2} x_{2}+\beta_{3} x_{3}+\beta_{12} x_{1} x_{2}+\beta_{13} x_{1} x_{3}+\beta_{23} x_{2} x_{3}+\varepsilon
$$

where $y$ is the response, $x_{1}, x_{2}, x_{3}, x_{1} x_{2}$ up to $x_{2} x_{3}$ represent values of factors $\mathrm{A}, \mathrm{B}, \mathrm{C}$ and interactions between the respective two factors (e.g. $x_{1} x_{2}$ represents the $\mathrm{AB}$ interaction).

The point estimate of the regression model is:

$$
y=\widehat{\beta}_{0}+\widehat{\beta}_{1} x_{1}+\widehat{\beta}_{2} x_{2}+\widehat{\beta}_{3} x_{3}+\widehat{\beta}_{12} x_{1} x_{2}+\widehat{\beta}_{13} x_{1} x_{3}+\widehat{\beta}_{23} x_{2} x_{3}
$$

where $\widehat{\beta}_{0}, \widehat{\beta}_{1}$, up to $\widehat{\beta}_{23}$ are estimates of the regression model coefficients that can also be calculated using the effects [17]. Values of all model coefficients and the value of the determination coefficient in $\%$ are shown in Table 7 .

\subsection{Designs of experiment for minimum response values}

Almost in all the monitored intervals for the minimum values of measured tensile strength of CBs, statistical significance of main factors and first-order interactions was not confirmed, with the exception of the 800 and $1250 \mathrm{~N} / \mathrm{mm}$ interval, where the significance of factor $\mathrm{A}$ was manifested (nominal strength), Fig. 5.

Table 8 shows the average values of the response on the upper

Table 8. The main effects of factors

\begin{tabular}{lccc}
\hline \hline 800 \& 1250 & A & B & C \\
$\bar{y} \cdot$ - (low level) & 890 & 1180.25 & 1108.25 \\
$\overline{y \cdot}$ - (high level) & 1384 & 1093.75 & 1165.75 \\
Effect of factors & 494 & -86.5 & 57.5 \\
\hline 800 \& 1000 & & & \\
$\bar{y} \cdot-$ (low level) & 890 & 1026 & 1017.75 \\
$\overline{y \cdot}$ - (high level) & 1139.25 & 1003.25 & 1011.5 \\
Effect of factors & 249.25 & -22.75 & -6.25 \\
\hline 1000 \& 1250 & & & \\
$\bar{y} \cdot-$ (low level) & 1139.25 & 1294.75 & 1260.5 \\
$\overline{y \cdot}$ (high level) & 1384 & 1228.5 & 1262.75 \\
Effect of factors & 244.75 & -66.25 & 2.25 \\
\hline \hline
\end{tabular}

Table 7. The coefficients point estimate of the regression model

\begin{tabular}{ccccccccc}
\hline \hline & $\begin{array}{c}\text { coeffi- } \\
\text { cient }\end{array}$ & $\hat{\beta}_{0}$ & $\hat{\beta}_{1}$ & $\hat{\beta}_{2}$ & $\hat{\beta}_{3}$ & $\hat{\beta}_{12}$ & $\hat{\beta}_{13}$ & $\hat{\beta}_{23}$ \\
\hline $\mathbf{8 0 0} \& 1000$ & value & 1110.88 & 131.12 & 10.37 & 20.13 & -0.87 & -29.63 & 18.12 \\
$\mathbf{1 0 0 \%}$ & p-value & 0.000 & 0.001 & 0.008 & 0.004 & 0.090 & 0.003 & 0.004 \\
\hline $\mathbf{8 0 0 \& 1 2 5 0}$ & value & 1292.75 & 313 & 38.25 & 63.75 & 27.00 & 14.00 & 16.25 \\
$\mathbf{9 9 . 9 7 \%}$ & p-value & 0.001 & 0.004 & 0.033 & 0.020 & 0.047 & 0.090 & 0.078 \\
\hline $1000 \& 1250$ & value & 1423.88 & 181.88 & 37.38 & 34.12 & 27.87 & 43.62 & 16.13 \\
$\mathbf{9 9 . 9 4 \%}$ & p-value & 0.001 & 0.007 & 0.032 & 0.035 & 0.043 & 0.027 & 0.074 \\
\hline \hline
\end{tabular}
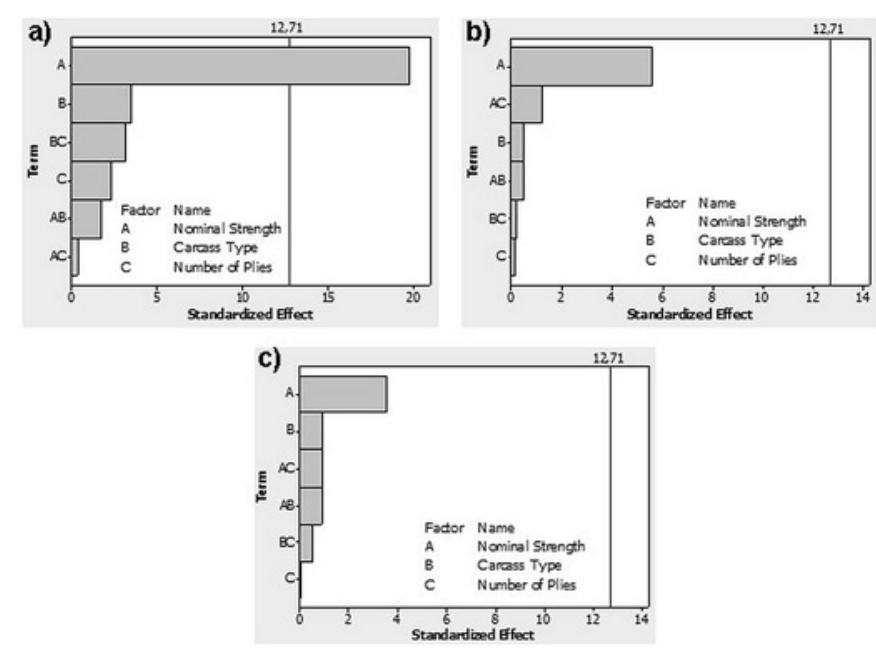

Fig. 5. The Pareto chart of the significance of factors and interactions; a) 800 and $1250 \mathrm{~N} / \mathrm{mm}, b) 800$ and $1000 \mathrm{~N} / \mathrm{mm}, \mathrm{c}) 1000$ and $1250 \mathrm{~N} / \mathrm{mm}$ and lower level of each factor, as well as effects of individual factors. Again, the strongest impact on the monitored response in all strength intervals was observed in factor A (nominal strength), even though it is not significant in all intervals. The values of all model coefficients and the value of the determination coefficient in $\%$ are shown in Table 9 .

\section{Discussion}

This paper is focused on the experimental research of the tensile strength of fabric conveyor belts. The research was carried out applying the Design of Experiment method (DOE), whereas the relation between the strength properties of conveyor belts was monitored in the selected factors. Six experiments were designed, in which 12 conveyor belts types were used with the nominal strength of 800,1000 and $1250 \mathrm{~N} / \mathrm{mm}$. Conveyor belts of the same nominal strength were also differing in the number of plies and the material of the textile carcass. In all experiments, the setting of factors $\mathrm{B}$ and $\mathrm{C}$ values (type of carcass and number of plies) was identical. Only the upper and lower levels of factor A were changing (nominal tensile strength).

In all the monitored intervals for the maximum values of the measured tensile strength of CBs, significant impact of all examined factors - the nominal tensile strength (factor A), a type of carcass (factor B), and the number of plies (factor $\mathrm{C}$ ) on the response (tensile strength of a conveyor belt) was confirmed. Also the impact of some interactions on the given dependent variable was manifested. The scope of the experimental program did not allow supplementation of one more factor. The setting of the strength interval has thus a decisive impact on 
Table 9. The coefficients point estimate of the regression model

\begin{tabular}{ccccccccc}
\hline \hline & $\begin{array}{c}\text { coeffi- } \\
\text { cient }\end{array}$ & $\hat{\beta}_{0}$ & $\hat{\beta}_{1}$ & $\hat{\beta}_{2}$ & $\hat{\beta}_{3}$ & $\hat{\beta}_{12}$ & $\hat{\beta}_{13}$ & $\hat{\beta}_{23}$ \\
\hline $800 \& 1000$ & value & 1014.63 & 124.63 & -11.38 & -3.13 & 10.13 & -27.63 & -4.62 \\
$100 \%$ & p-value & 0.014 & 0.113 & 0.701 & 0.912 & 0.729 & 0.433 & 0.870 \\
\hline $800 \& 1250$ & value & 1137 & 247 & -43.25 & 28.75 & -21.75 & 4.25 & -39.50 \\
$98.34 \%$ & p-value & 0.007 & 0.032 & 0.179 & 0.261 & 0.332 & 0.791 & 0.195 \\
\hline $1000 \& 1250$ & value & 1261.63 & 122.38 & -33.13 & 1.12 & -31.88 & 31.88 & -17.12 \\
$56.60 \%$ & p-value & 0.018 & 0.177 & 0.516 & 0.979 & 0.529 & 0.529 & 0.709 \\
\hline \hline
\end{tabular}

Table 10. Significant factors and interactions in the monitored intervals for the minimum and maximum values of the measured tensile strength of $C B s$

\begin{tabular}{ccc}
\hline \hline \multirow{2}{*}{ Strength interval } & \multicolumn{2}{c}{ Factors and interactions } \\
\cline { 2 - 3 } 800 and 1250 & MIN & MAX \\
800 and 1000 & - & $A, C, B, A B$ \\
1000 and 1250 & - & $A, A C, C, B C, B$ \\
\hline \hline
\end{tabular}

Table 11. Interval range for the maximum measured values

\begin{tabular}{cccc}
\hline \hline \multirow{2}{*}{ Strength interval } & \multicolumn{3}{c}{ [\%] } \\
\cline { 2 - 4 } $\mathbf{8 0 0}$ and 1250 & MIN & MAX & Interval range \\
$\mathbf{8 0 0}$ and 1000 & 15.4 & 41 & 25.7 \\
1000 and 1250 & 20.5 & 26 & 10.6 \\
\hline \hline
\end{tabular}

Table 12. Interval range for the minimum measured values

\begin{tabular}{cccc}
\hline \hline \multirow{2}{*}{ Strength interval } & \multicolumn{3}{c}{$[\%]$} \\
\cline { 2 - 4 } $\mathbf{8 0 0}$ and 1250 & MIN & MAX & Interval range \\
800 and 1000 & 7.5 & 22.7 & 15.2 \\
1000 and 1250 & 9.2 & 18.9 & 11.4 \\
\hline \hline
\end{tabular}

the determination of the impact of factors. In the monitored intervals for the minimum values of the measured tensile strength of CBs, only the statistically significant impact of factor A was confirmed (nominal strength) in the interval of 800 and $1250 \mathrm{~N} / \mathrm{mm}$. The list of all significant factors and interactions is presented in Table 10 .
The differences between the measured tensile strength and the nominal strength of conveyor belts were used to determine the range of individual strength intervals. On the basis of the maximum (MAX) and the minimum (MIN) values, separately for the maximum (Table 11) and minimum (Table 12) measured values, the strength interval range was determined. With the falling interval range in the maximum measured values, the number of more significant interactions is rising. However, in the minimum measured values, particularly in the broadest strength interval of 800 and $1250 \mathrm{~N} / \mathrm{mm}$, significance of factor A was confirmed.

\section{Conclusions}

During the operation, a conveyor belt is exposed mainly to the uniaxial quasi-static tensile stress in the lengthwise direction, due to its required initial tension for the transfer of tensile forces and the dynamic stress in the transverse direction induced by its troughability. Improper dimensioning of conveyor belt mechanical properties and selection of inappropriate cover layers or a conveyor belt carcass can result in the belt rupture. Therefore, the experimental research was focused on the testing of tensile strength of fabric conveyor belts, while monitoring the relation between the mechanical properties of conveyor belts and the selected factors. To achieve improved strength parameters of conveyor belts, it is important to identify possible impact of input factors. Using the DOE method, factors and their interactions affecting the response - tensile strength of a conveyor belt were identified. The impact of three monitored factors was confirmed, i.e. the nominal strength (factor A), the number of plies (factor C), and the type of carcass (factor B), as well as certain mutual interactions, for the maximum values of the measured strength. In certain two-factor interactions, however, statistically significant impact was not confirmed.

The results indicate that the nominal strength has the strongest impact on the tensile strength of a conveyor belt, i.e. on the monitored response in all experiment designs, although it is not significant in each case. In the examined responses, the relation between the DOE method and the range of the input experimental data was not manifested.

Regression models were also determined to describe the functional relation of the output characteristics and the input factors. Each obtained regression model represents a complete three-factor experiment containing factors and first-order interactions.

\section{Acknowledgement}

This article is the result of the Project implementation: University Science Park TECHNICOM for Innovation Applications Supported by Knowledge Technology, ITMS: 26220220182, supported by the Research \& Development Operational Programme funded by the ERDF. "We support research activities in Slovakia/This project is being co-financed by the European Union"

\section{References}

1. Andrejiová M, Pavlisková A. Analysis of regression model of functional dependency in impact force from height and weight of ram for conveyor belt. Annals of Faculty Engineering Hunedoara 2010; 8 (3): 267-270.

2. Andrejiová M, Pavlisková A, Marasová ml. D, Husáková N. The design an experiment the stress of the conveyer belts. Transport and Logistics 2012; Mimoriadneč. 10: 242-248.

3. Beljič $\breve{C}$, Lazovič M. Risk assesment in underground mine plant. Transport and Logistics 2001; 1: 123-127.

4. Berežný Š, Grinčová A. Regresná analýza špecifických matematických modelov získaných pri skúškach dopravných pásov proti prierazu. Transport and Logistics 2010; Mimoriadneč. 7: 296-308.

5. Du D M, Li H, Zhu C S, He Q. Virtual prototype modeling and starting method of belt conveyor. Applied Mechanics and Materials 2011; 148-149: 879-882, http://dx.doi.org/10.4028/www.scientific.net/AMM.148-149.879.

6. Drottboom M. A rising global trend. New technological developments increase range of IPCC applications. Bulk Solids Handl. 2013; 33 (5): $22-26$. 
7. Grinčová A, Hlúbiková A, Krešák J. Metodika skúšania dopravných pásov pri prieraze. Transport and Logistics 2008; Mimoriadneč. 5: $209-213$.

8. Grinčová A, Marasová D. Experimental research and mathematical modelling as an effective tool of assessing failure of conveyor belts. Eksploatacja i Niezawodnosc - Maintenance and Reliability 2014; 16 (2): 229-235.

9. Grujic M, Andrejiova M, Marasova D, Grendel P. Using the DOE method by experimental research of conveyor belts quality. TTEM Journal: Technics Technologies Education Management 2013; 8 (2): 558-564.

10. Hardygora M. Trends in conveyor belt research. Transport and Logistics 2002; 3: 1-12.

11. ISO 18573: 2013, Coveyor belts - Test atmospheres and conditioning periods.

12. Kulinowski P. Simulation studies as the part of an integrated design process dealing with belt conveyor operation. Eksplotacja i Niezawodnosc - Maintenance and Reliability 2013; 15 (1): 83-88.

13. Leng Y F, Liu J, Zu F. Parametric design on belt conveyor drums based on VBA. Adv Mater Res 2010; 156-157: 1243-1246, http://dx.doi. org/10.4028/www.scientific.net/AMR.156-157.1243.

14. Luo X, Li T, Hu B, Zheng M, Peng Q J. The modeling and simulating of conveyor belt based on ADAMS. Adv Mater Res 2012; 562-564: 1451-1455, http://dx.doi.org/10.4028/www.scientific.net/AMR.562-564.1451.

15. Maneski T, Jovančić P, Ignjatović D, Milošević-Mitić V, Maneski M. Condition and behaviour diagnostics of drive groups on belt conveyors. Eng. Failure Anal. 2012; 22: 28-37, http://dx.doi.org/10.1016/j.engfailanal.2012.01.001.

16. Marasová D. Mathematical and experimental support for belt conveyors. Ostrava: VŠB-TU, 2013.

17. Montgomery D C. Design and Analysis of Experiments. New York: J. Wiley, 2002.

18. Röthemeyer F, Sommer F. Kautschuk Technologie, München Wien: Carl Hanser Verlag, 2006.

19. STN 26 0370: 1987, Dopravné pásy s textilnou kostrou - Metódy skúšania základných vlastnosti.

20. STN EN ISO 283: 2007, Textilné dopravné pásy - Pevnost' v t’ahu v celej hrúbke dopravného pása, predíženie pri pretrhnutí (t’ažnost') a predíženie pri referenčnom zatažení - Skúšobná metóda.

21. Šaderová J, Rosová A, Bindzár P, Kačmáry P. Multi-Criteria evaluation - A tool for the selection of steel wire rope. Applied Mechanics and Materials 2014; 683: 33-38, http://dx.doi.org/10.4028/www.scientific.net/AMM.683.33.

22. Vladimír T. The methods of conveyor belt basic characteristics testing and special tests. Transport and Logistics 2004; 4 (6): 59-68.

23. Turnbull D. A game changer in Mining. IPCC and continuous mining solution are set to gain more Ground. Bulk Solids Handl. 2013; 33 (5): 16-18.

24. Valentova H, Skrbek B, Neubert M, Hana P, Nedbal J. Mechanical and ultrasound properties of conveyor belt rubbers. in: SGEM2011 Conference Proceedings, Bulgaria, 2011: 839-844, http://dx.doi.org/10.5593/sgem2011/s03.125.

25. Wang F S. Indentation rolling resistance of conveyor belts based on Maxwell model. Adv Mater Res 2012; 479-481: 1526-1529, http:// dx.doi.org/10.4028/www.scientific.net/AMR.479-481.1526.

26. Westphal H. Optimierung von Fördergurten mit Textil-Einlagen. Hebezeuge Fördermittel 1985; 25 (3): 81-85.

27. Zwick Materials Testing Machines [online]. [cit. 2015-03-30]. <http://www.zwick.com/en/products/static-materials-testing-machines. $\mathrm{html}>$

\section{Ĺubomír AMBRIŠKO \\ Daniela MARASOVÁ}

Institute of Logistics

Faculty of Mining, Ecology, Process Control and

Geotechnologies

Technical University of Košice

Letná 9, 04001 Košice, Slovakia

\section{Peter GRENDEL}

Driving School Grendel

Secondary School Automobile

Moldavská 2, 04011 Košice, Slovakia

E-mail: lubomir.ambrisko@tuke.sk, daniela.marasova@tuke.sk, grendel@grendel.sk 